\title{
Türkiye Sanayi Elektrik Enerjisi Tüketiminin 2017-2023 dönemi için Yapay Sinir Ağları ile Tahmini ${ }^{1}$
}

\author{
İhsan PENÇE ${ }^{1 *(D)}$, Adnan KALKAN ${ }^{2}$ (D) , Melike Şİ̧ECİ ÇEŞMELI ${ }^{3}$ \\ ${ }^{1}$ Asst. Prof. Dr., Burdur Mehmet Akif Ersoy University, Faculty of Engineering and Architecture \\ Department of Computer Engineering, Burdur, Turkey \\ ${ }^{2}$ Prof. Dr., Burdur Mehmet Akif Ersoy University, Bucak Zeliha Tolunay School of Applied Technology and \\ Management, Department of Management Information Systems, Burdur, Turkey \\ ${ }^{3}$ Asst. Prof. Dr., Burdur Mehmet Akif Ersoy University, Bucak Zeliha Tolunay School of Applied Technology \\ and Management, Department of Management Information Systems, Burdur, Turkey
}

Geliș Tarihi/Received: 12.03.2019

Kabul Tarihi/Accepted: 05.07.2019
Doi: doi.org/10.31200/makuubd.538878

Araştırma Makalesi/Research Article

\section{ÖZET}

Ülkelerin gelişmesinde sanayinin büyük bir rolü olup geçmişten günümüze kadar sanayi faaliyetleri hız kesmeden ilerlemiştir. Bu gelişime ayak uyduran ülkeler ucuz hammaddeleri işleyip yüksek ücretlere satarak hazinelerini genişletmişlerdir. Endüstri 4.0 devriminin şafağında bu gelişimden geri kalınmaması gerekmekte olup gerek sanayi gerekse teknoloji birlikte geliştirilmelidir. Sanayileşmedeki en büyük ihtiyaçlardan biri elektrik enerjisi olup Türkiye'de elektrik enerjisi tüketiminin sanayi için oranları yıllara göre $\% 40$ ile $\% 60$ arasında değişmektedir. $\mathrm{Bu}$ oranlar düşünüldüğünde elektrik tüketiminin büyük bir payı sanayiye ait olup ileriye yönelik planlamaların yapılmasına kesinlikle ihtiyaç duyulmaktadır. Türkiye'nin Endüstri 4.0 ile birlikte gelecek planlarında elektrik enerjisi sıkıntısına düşmemesi için ileriye yönelik tahminleme ve buna uygun yeni tesislerin kurulumlarının planlanması gerekmektedir. Bu çalışmada, Türkiye'de 1970-2016 yıllarına ait sanayi için elektrik tüketimleri yapay sinir ağları ile modellenmiş olup elde edilen model daha sonra 2017-2023 yıllarındaki tüketimi tahmin etmek için kullanılmıştır. Yapay sinir ağı birisi-dışarıda çapraz doğrulama yöntemi ile test edilmiş olup elde edilen sonuçlara göre; ortalama karesel hataların karekökü değeri 8.99, ortalama mutlak yüzde hata $\% 31.6$ ve belirleme katsayısı ise 0.94 olarak elde edilmiş olup bu sonuçlar modelin iyi kurulduğunu ortaya koymaktadır. Ayrıca 2023 yılına kadar olan tahmin

\footnotetext{
${ }^{1}$ Bu çalışma, Uluslararası EMI Sosyal Bilimler Kongresinde (EMISSC 2018) sözlü olarak sunulan çalışmanın genişletilmiş halidir.

* Sorumlu yazar/Corresponding author

E-mail/e-ileti: ihsanpence@mehmetakif.edu.tr 
değerleri de Türkiye Elektrik İletim A.Ş. Genel Müdürlüğü’nün kendi tahminleri ile paralellik göstermektedir.

Anahtar kelimeler: Elektrik Tüketimi, Sanayi, Yapay Sinir Ağları, Tahminleme.

\title{
Estimation of Turkey Industrial Electricity Consumption with Artificial Neural Networks for the 2017-2023 Period
}

\begin{abstract}
In the development of the countries, the industry played a big role and the industrial activities from the past to the present day progressed without slowing down. These developments have expanded their treasury by selling cheap raw materials to high wages after they have grown up. At the dawn of the Industry 4.0 revolution, this development should not be left behind, and both industry and technology should be developed together. For industrialization, one of the biggest needs is electricity energy and the ratio of consumption of electricity energy in proportion to industry in Turkey ranges from $40 \%$ to $60 \%$ according to years. Considering these rates, a large share of electricity consumption belongs to the industry and there is absolutely a need for future planning. Turkey's future plans with Industry 4.0, forecasting electricity for onward fall into distress, and it is necessary to install the proper planning of new facilities. In this study, the electricity consumption of the 1970-2016 years for the industry in Turkey are modeled with artificial neural network, then obtained successful model is used to estimate consumption in the years 2017-2023. The artificial neural network has been tested by leave-one-out cross validation method and according to the results; the root mean square error is 8.99 , the mean absolute percentage error is $31.6 \%$, and the coefficient of determination is 0.94 , which indicates that the model is well established. In addition, forecast values up to 2023 are in line with General Directorate of Türkiye Elektrik İletim A.Ş.'s own estimates.
\end{abstract}

Keywords: Electricity Consumption, Industry, Artificial Neural Networks, Estimation.

\section{GIRIŞ̧}

Ülkelerin kalkınmasında ve gelişmişlik seviyelerinde sanayinin büyük bir rolü olup geçmişten günümüze kadar sanayi faaliyetleri hız kesmeden bu doğrultuda ilerlemiştir. $\mathrm{Bu}$ değişime ayak uyduran ülkeler ucuz hammaddeleri işleyip yüksek ücretlere satarak hazinelerini genişletip gelişmişlerdir. Endüstri 4.0 devriminin yaşanmaya başladığı günümüzde Türkiye'nin de bu değişimden geri kalmaması için gerek sanayisini gerekse teknolojisini birlikte 
geliştirmesi gerekmektedir. Bu sürece elektrik enerjisinin etkisi de elbette tartışılamazdır. Elektrik enerjisi, kullanım kolaylığı ve atık bırakmaması gibi özellikleri sebebiyle diğer enerji kaynaklarına göre genel enerji tüketimi içinde daha yüksek payı almaktadır. Bunun yanında elektrik enerjisinin depolanamaması sebebiyle üretildiği anda tüketilmesi gerekmekte olup elektriğin sağlıklı ve yüksek verimle kullanılabilmesi için, elektrik enerjisi tüketilen miktar kadar üretilmesi gerekmektedir (Eke, 2011).

Sanayileşmede en büyük ihtiyaçlardan biri elektrik enerjisi olup Türkiye' de elektrik enerjisi tüketiminin sanayi için oranları yıllara göre yaklaşık $\% 40$ ile $\% 60$ arasında değişmektedir (TUIK, 2018). Şekil 1'de 2016 y1lı elektrik tüketiminin tüketici türüne göre dağılımı görülmektedir (EPDK, 2018).

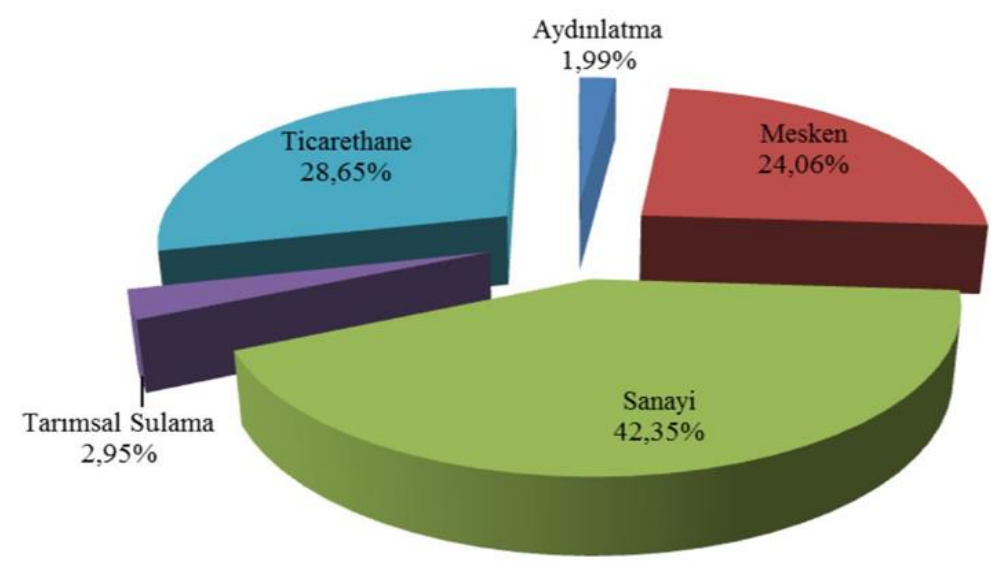

Şekil 1. 2016 Yılı Elektrik Tüketiminin Tüketici Türüne Göre Dağılımı (EPDK, 2018)

Şekil 1'de de görülen oranlar düşünüldüğünde elektrik tüketiminin büyük bir pay1 sanayiye ait olup ileriye yönelik planlamaların yapılmasına kesinlikle ihtiyaç duyulmaktadır. Türkiye'nin Endüstri 4.0 ile birlikte gelecek planlarında elektrik enerjisi sıkıntısına düşmemesi için ileriye yönelik tahminleme ve buna uygun yeni tesislerin kurulumlarının planlanması gerekmektedir.

Elektrik enerjisine olan talep nüfusunda artmasıyla birlikte günden güne artmakta olup Türkiye dışında diğer ülkeler de değişimleri değerlendirip, sonraki 10 yıllık ve daha fazla süreli enerji politikalarını oluşturmaktadırlar. Bunu gerçekleştirirken de elektrik enerjisi taleplerinin tahmini ve buna uygun yatırım planları yapılmaktadır. Ayrıca elektrik fiyatlarının hesaplanabilmesi için de bu tahminler gerekmektedir.

Türkiye'nin sahip olduğu elektrik sisteminde hidrolik, rüzgâr, termik, jeotermal, güneş ve biyokütle kaynaklı santraller bulunmaktadır. Nükleer santral ise henüz kurulum 
aşamasındadır. Bir santralin herhangi bir zamanda arızalanması ve üretim yapamaması veya eksik üretim yapması bu santrallerden elde edilebilecek elektrik miktarını da doğrudan etkilemektedir. Elektrik üreten santrallerin üretim yapamaması veya eksik üretim yapmasının sebepleri arasında ilk başta arızalar gelirken bunun yanında termik santraller için yakıt yetersizliği veya yakıt kalitesi, hidrolik santraller için su miktarındaki azlık ve rüzgâr santralleri için ise rüzgâr esmemesi veya rüzgârın yetersiz olması da gelmektedir. Üretim yapamayacak durumda olan kapasite düşürüldükten sonra her an elektrik üretmeye hazır durumda olan kapasiteye Emreamade Kapasite denilmekle birlikte bu kapasite enerji sıkıntısına düşülmemesi için doğru bir şekilde hesaplanmalıdır. Bunun yanında elektrik tüketimi miktarının yıl içinde belirli ay ve günlerde değişebildiği düşünüldüğünde belirli yedek kapasitenin de ayrılması gerekmektedir. Emreamade Kapasite ile yedek kapasite düşünüldüğünde elektrik ihtiyacını karşılayacak miktarların belirlenip projelendirilmesinde ise talep edilen miktar yani tüketim değerleri büyük öneme sahiptir. Bu sebeple ileriye yönelik elektrik tüketimi tahmininin de önemi anlaşılabilmektedir (TEİAŞ, 2018).

Türkiye elektrik enerjisi toplam kurulu gücünün kaynaklara göre geçmişteki gelişimi ve önümüzdeki dönemde beklenen gelişmeler incelendiğinde Şekil 2'deki gibi bazı kaynakların miktar olarak arttığı, bazılarının ise sabit kaldığı görülmektedir. Bunun yanında kabul edilen projelerde hesaba katılıp yıllar bazında toplam kurulu gücün içerisinde kaynakların oranları incelendiğinde bu oranların değişiklik gösterdikleri görülmektedir (TEİAŞ, 2018).

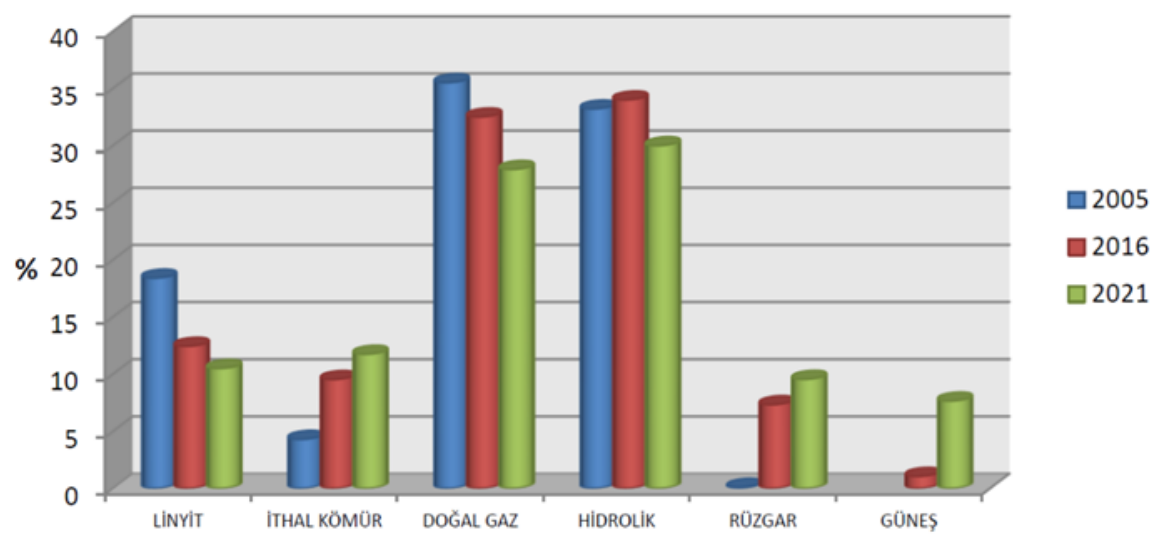

Şekil 2. Kaynakların Türkiye toplam kurulu gücündeki oranları (TEİAŞ, 2018)

Şekil 2'de de görüldüğü gibi kaynakların toplam kurulu güce oranları yıllara göre değişmekle birlikte 2021 yllında özellikle güneş enerjisi ile elektrik elde edilmesindeki oranın diğer kaynaklara oranla daha yüksek olacağı görülmektedir. 
Gerek Türkiye gerekse diğer ülkeler ileriye yönelik 5'er ve 10'ar yıllık dönemler için elektrik enerjisi ihtiyaç talebi belirlemektedir. Literatürde elektrik tüketimine ilişkin tahminlemede yapay zekâ teknikleri dahil birçok yöntem kullanılmıştır. Bu çalışmalar içerisinde çoğunlukla toplam elektrik tüketimi dikkate alınmış olup sanayi alanında tüketilen elektrik miktarları az bulunmaktadır. Bunun yanı sıra çoğu çalışma tüketim miktarlarını belirlerken sıcaklık, gayrisafi milli hâsıla (GSMH), sanayi üretim endeksi ve günlere ilişkin tatil, hafta içi, hafta sonu olması gibi bilgileri kullanmaktadır. Bu çalışmanın diğer çalışmalardan farklı olan yanlarından birisi de sadece yıl bilgisi kullanarak sanayi alanında elektrik tüketimi değerlerini modelleyip tahmin edebilmesidir. Literatürde Türkiye'de elektrik tüketim tahminlerine yönelik çeşitli çalışmalar gerçekleştirilmiş olup en çok yapay sinir ağları (YSA), regresyon ve zaman serileri analizlerinin sıklıkla kullanıldı̆̆ı görülmektedir.

Yapılan çalışmalar incelendiğinde YSA yöntemi sıklıkla kullanılmış olup; ileri beslemeli YSA çalışmaları (Hamzaçebi, 2007; Kavaklioglu vd., 2009; Oğcu vd., 2012; Biricik vd., 2015; Kocadayı vd., 2017)'in yanında geri yayılım ağlarının kullanıldığı (Hamzaçebi ve Kutay, 2004) çalışmalarda mevcuttur. Gri tahminleme yöntemi de çeşitli çalışmalarda (Akay ve Atak, 2007; Boltürk, 2013) kullanılmıştır. Bulanık mantık ve Adaptif A ̆g Tabanlı Bulanık Çı1karım Sistemi (ANFIS)'inde yöntem olarak tercih edildiği (Kuçukali ve Baris, 2010; Boltürk, 2013; Bayramoğlu vd., 2017) görülmektedir. Otoregresif Hareketli Ortalamalar (ARMA) modeli Demirel ve arkadaşları (2010) tarafından kullanılırken, zaman serisi ve regresyon analizleri de birçok çalışmada (Dilaver ve Hunt, 2011; Balcı vd., 2012; Bilgili vd., 2012; Kavaklığlu, 2014; Arisoy ve Ozturk, 2014; Türkay, 2015; Çalık ve Şirin, 2017) kullanılmıştır. Destek Vektör Makinası (DVM) tabanlı modellerde literatürde elektrik tüketimi tahmini için sıklıkla (Küçükdeniz, 2010; Kavaklioglu, 2011; Kaytez vd., 2015; Oğcu vd., 2012) kullanılmaktadır. ARIMA modeli ise Boltürk (2013) tarafından uygulanmıştır.

$\mathrm{Bu}$ çalışmaların yanında hibrit yaklaşımlar da tahmin modellerinde kullanılmaktadır. YSA'nın çeşitli yöntemlerle birleştirildiği uygulamalar arasında; diferansiyel evrim (DE), genetik algoritma (GA) ve yapay arı kolonisi (YAK) gibi optimizasyon yöntemleri ile birlikte kullanılan çalışmalar (Eke, 2011; Yigit, 2011; Gürbüz vd., 2013; Kaynar vd., 2016) en çok karşılaşılan uygulamalar olurken, YSA ayrıca regresyon ve uzman sistemlerle birlikte de (Aydoğdu ve Yildiz, 2017; Başoğlu ve Bulut, 2017) kullanılmıştır.

Türkiye dışında diğer ülkelerde de elektrik tüketimi ile ilgili bazı çalışmalar yapılmıştır. Klasik ve hibrit yöntemlerin kullanıldığı çalışmalar incelendiğinde; regresyon analizini (Tso ve 
Yau, 2007; Bianco vd., 2009; Adom ve Bekoe, 2012; Bianco vd., 2013; Amber vd., 2015), ARIMA modelini (Veit vd., 2014; Yuan vd., 2016; Hussain vd., 2016; Cabral vd., 2017) ve gri tahminleme yöntemini (Li vd., 2012) kullanan çalışmalar yer alırken, YSA modelini kullanan çalışmalar arasında ileri beslemeli YSA sıklıkla (Ekonomou, 2010; Panklib vd., 2015; Dong vd., 2016) kullanılırken, Chae vd. (2016) YSA'yı bayes düzenlemesi ile birlikte uygulamıştır. Bulanık mantık ve bayes teorisi kullanan çalışmalar (Tang vd., 2019) ve DVM regresyonu kullanan çalışmalar da (Jain vd., 2014; Ahmad vd., 2014) mevcuttur. Bunların yanında optimizasyon ve derin öğrenmenin de elektrik tüketimi tahminlerinde kullanıldığı görülmekte olup, derin öğrenme metotları kullanan çalışmalar (Marino vd., 2016; Babich vd., 2019) ve optimizasyon kullanılan çalışmalar (Behrang vd., 2011; Kasule ve Ayan, 2019) dikkat çekmektedir.

Hibrit yaklaşım kullanan çalışmalara da sıklıkla rastlanmaktadır. Optimizasyonu diğer yöntemler ile birleştiren çalışmalar incelendiğinde; DVM ile birlikte kullanılan (Cao ve Wu, 2016), gri tahminleme ile kullanılan (Xu vd., 2017), YSA ile birlikte modellenen yaklaşımlar da (Li vd., 2015; Zeng vd., 2017) mevcuttur. Bunun yanında DVM ve gri tahminleme birçok çalışmada görülmekte ve bazı yöntemler ile birleştirilip kullanılmaktadır. Bunlar arasında, YSA veya konvolüsyonel sinir ağları ile birlikte (Hu, 2017; Torabi vd., 2019; Zhang ve Li, 2019) kullanılırken ARIMA ile birlikte de (Chou vd., 2019) kullanılmıştır. ANFIS ve ARIMA'yı birlikte kullanan bir çalışmada Barak ve Sadegh (2016) tarafından gerçekleştirilmiştir.

Yapılan çalışmalarda da görüldüğü gibi çoğunlukla toplam elektrik tüketimi dikkate alınmış olup sanayi alanında tüketilen elektrik miktarları konusunda eksiklik bulunmaktadır. $\mathrm{Bu}$ çalışma ile sanayi alanındaki tahminlemeye ilişkin bu boşluk kapatılıp yıl bilgisi ile gelecek planlaması yapılabilecektir.

Bu çalışmanın amacı Türkiye'nin sanayi alanında 2023 yılına kadar olan elektrik tüketimi değerlerinin tahmin edilmesidir. Bu sayede tüketim değerleri göz önüne alınarak mevcut üretim değerleri ve ileride gerçekleştirilecek projelerin elektrik ihtiyacını karşılayıp karşılayamayacağı tespit edilip öngörülebilecektir. Çalışmada yöntem olarak Yapay Sinir Ağları (YSA) kullanılmış olup tahminleme yapılmıştır (Özsoy ve Fırat, 2004; Akyılmaz ve Ayan, 2006).

\section{MATERYAL VE METOT}


Bu çalışmada elde edilen verilerin modellenmesi ve ileriki yılların tahmini için ileri beslemeli YSA yöntemi kullanılmıştır.

\subsection{Araştırmanın Amacı ve Kapsamı}

Araştırmanın temel amacı Türkiye'de 2023 yılına kadar sanayilerde tüketilen elektrik miktarının tahminini gerçekleştirmektir. Bunun için de öncelikle TUIKK'den (TUİK, 2018) elde edilen 1970-2016 yıllarına ait veriler kullanılarak bir YSA modeli oluşturulmuştur. Daha sonra bu model ile 2017-2023 yıllarına ait elektrik tüketim miktarları Gigawatt Saat (GWh) cinsinden tahmin edilmiştir. Bu sayede Türkiye'nin ileriye dönük planlarında elektrik üretimini hangi seviyelerde tutması ve ne kadar yeni tesis kurması gerektiğine ilişkin bilgiler edinilebilecektir.

\subsection{Veri Seti ve Ölçeklendirme}

Bu çalışmada YSA modelini eğitmek ve test etmek amacıyla TUİK'in (TUİK, 2018) yayınladığ 1970-2016 yıllarındaki sanayi alanında elektrik tüketimini kapsayan toplam 47 adet veri kullanılmıştır. Fakat bu veriler Türkiye Elektrik İletim A.Ş. Genel Müdürlüğü’nün (TEİAŞ) yayınladığı (TEİAŞ, 2018), Enerji Piyasası Düzenleme Kurumu'nun (EPDK) yayınladığı (EPDK, 2018) ve Enerji ve Tabii Kaynaklar Bakanlığı'nın (ETKB) yayınladığı (ETKB, 2018) değerlere göre farklılık göstermektedir. EPDK'nın raporunda elektrik taleplerinin brüt talep olduğu belirtilmiş olup, iletim ve dağıtım hatlarındaki kayıplar ve kaçak ile santrallerin iç ihtiyaçlarının bu değerlere dahil oldukları belirtilmiştir. Bunun yanında dağıtım sistemine bağlı ve Yük Tevzi Merkezinden talimat almayan üretim tesislerinin üretimlerinin de bu değerlere eklendiği ifade edilmektedir (EPDK, 2018). Dolayısıyla aradaki farkın bu sebepler ile oluştuğu düşünülmektedir. YSA modelini daha iyi eğitebilmek ve daha kararlı sonuçlar alabilmek için çok sayıda veriye ihtiyaç duyulması sebebiyle ve TUİK dışında sanayi kapsamında tüketilen elektrik miktarlarının geçmiş yıllara ait verilerinin yayınlanmaması sebebiyle TUİK verilerine yönelinmiştir. Aradaki enerji değerleri incelendiğinde 2000-2016 yıllarına ait açıklanan toplam elektrik tüketimi değerlerinde yaklaşık aynı oranda farklılık tespit edilmiştir. Bu fark ortalama \%24.5 olup standart sapma değeri de 2.99 olarak bulunmuştur. Standart sapma değerinin düşük çıkması sebebiyle elde edilen ortalama fark değeri 1970-1999 y1llarına ait bilinmeyen sanayi tüketim değerlerini ölçeklendirmek için kullanılmıştır. Aynı zamanda TEİAŞ'ın kendi tahminleri ile YSA tahminlerinin (TEİAŞ, 2018) kıyaslanmasında da bu orandan faydalanılmıştır. Tablo 1'de 
yapay zekâ modeli için öznitelik ve çıtı değerlerini içeren veri setine ait bazı örnekler yer almaktadir.

Tablo 1. Türkiye sanayi elektrik enerjisi tüketimi veri seti

\begin{tabular}{|c|c|}
\hline Öznitelik & Çıktı \\
\hline Yıllar & Elektrik Tüketimi (GWh) \\
\hline 1970 & 5.84 \\
\hline 1971 & 6.65 \\
\hline 1972 & 7.71 \\
\hline$\vdots$ & $\vdots$ \\
\hline 2014 & 121.40 \\
\hline 2015 & 126.47 \\
\hline 2016 & 130.52 \\
\hline
\end{tabular}

Tablo 1'de de görüldüğü gibi veri seti öznitelik olarak y1l bilgisini içermekte olup çıtı değeri olarak da sanayi alanında tüketilen elektrik enerjisini GWh cinsinden içermektedir.

\subsection{Yapay Sinir Ağı Modeli ve Hata Kriteri}

YSA, insan beyninin çalışma şekli ilham alınarak oluşturulmuş, sinir hücreleri olan nöronları içeren bir algoritmadır. YSA'nın da aynı insan zekâsı gibi eğitilip öğrenme özellikleri olup bunu gerçekleştirmek için örnekleri kullanmaktadır (Özsoy ve Fırat, 2004; Akyılmaz ve Ayan, 2006). Bir nöron kendisine gelen sinyalleri $\left(g_{j}\right)$ geldikleri nöronlarla olan sinaptik bağlantıların ağırlıkları $\left(w_{i, j}\right)$ ile çarparak toplar ve buna varsa bias $\left(b_{i}\right)$ terimini de ekleyerek elde edilen sonucu $(n)$ tanımlanmış aktivasyon fonksiyonuna $(f)$ iletir. Parametresi $\mathrm{n}$ olan aktivasyon fonksiyonu da skaler nöron çıktısı olan a değerini üretmektedir. Herhangi bir ara katmandaki i-inci nöronun yapısı Şekil 3'te görülmektedir.

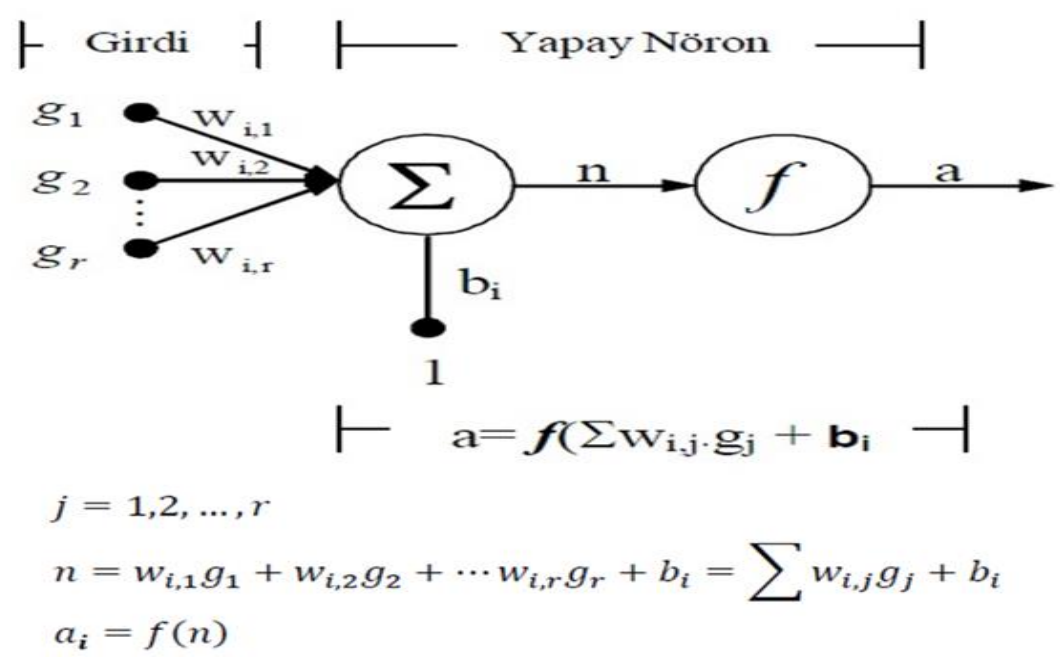

Şekil 3. Gizli katmandaki herhangi bir nöronun yapısı 
Şekil 3 'te de görülen nöron yapısında aktivasyon fonksiyonu olarak sigmoid, hiperbolik tanjant, doğrultucu (ReLU) gibi fonksiyonlar kullanılabilmektedir (Qiu, 2017).

YSA ağ tipine bağlı olarak genellikle ileri beslemeli, çok katmanlı ve geri beslemeli olarak ayrılmaktadır. Öğrenme stratejisi açısından ise YSA genellikle danışmanlı (Supervised) öğrenme, danışmansız (Unsupervised) öğrenme ve destekleyici (Reinforcement) öğrenme olmak üzere 3 kategoriye ayrılmaktadır. YSA'nın literatürde farklı çeşitleri bulunmakta olup bunlar arasında; algılayıcı (perceptron), ileri beslemeli, tekrarlayan sinir ağı, derin ileri beslemeli, uzun-kısa vadeli bellek (LSTM), yarıçapsal temelli ăg (Radial Basis Network), otomatik kodlayıcı, derin inanç ağı ve konvolüsyonel sinir ağları gelmektedir (Goodfellow vd., 2016).

$\mathrm{Bu}$ çalışmada ileri beslemeli sinir ağ yapısı kullanılmış olup, bu yapıda hücreler katmanlar şeklinde düzenlenir ve bir katmandaki hücrelerin çıkışları yalnızca bir sonraki katmana ağırlıklar üzerinden giriş olarak verilebilir. Bilgi, orta ve çıkış katmanında işlenerek ağ çıkışı belirlenir. Girdileri oluşturan verilerin uygulandığı katman giriş katmanı, sonuç değerlerine ait çıkışların alındığı katman ise çıkış katmanıdır. Giriş ve çıkış katmanlarının arasında gizli (saklı) katmanlar bulunur. Giriş ve çıkış katmanlarındaki nöron sayıları ele alınan problemin gereklerine göre artırılabilir veya azaltılabilmektedir (Arslan ve İnce, 1996; Fırat ve Güngör, 2004). Bu çalışmada tüketim değerlerinin tahmini yapıldığı için eğri uydurma modeli olan tek çıkışlı YSA yapısı kullanılmış olup Şekil 4’te görülmektedir.

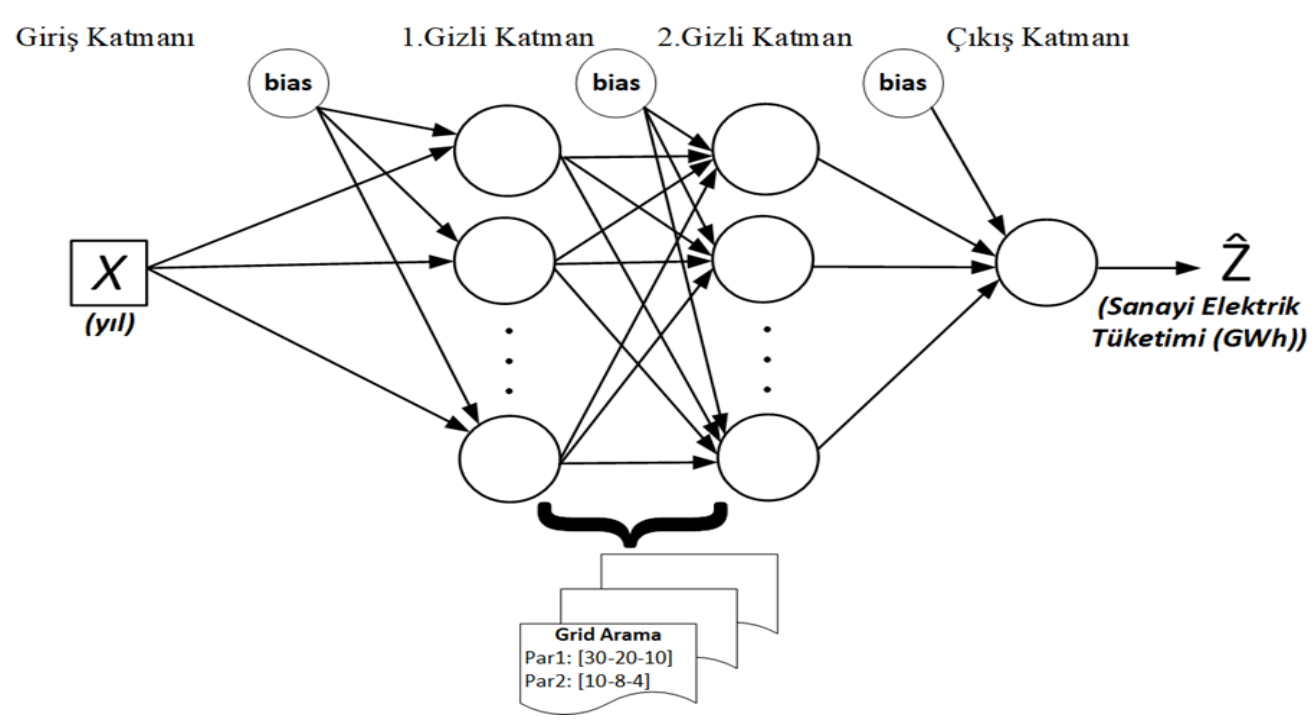

Şekil 4. Sanayi elektrik tüketimi tahmini için oluşturulan YSA modeli 
Şekil 4'te de görülen ve çalışmada kullanılan ileri beslemeli YSA modelinin giriş katmanında girdi olarak sadece yıl bilgisi bulunmaktadır. Gizli katmanlar için 2 adet katman kullanılmış olup en iyi performans için bunların kaçar adet nöron içereceği farklı nöron sayıları ile grid arama yöntemi ile test edilip belirlenmiştir. Grid arama, belirtilen her hiperparametre kombinasyonu için bir model oluşturur ve her bir modeli ayrı ayrı değerlendirir (Pillai vd., 2019). Grid arama yönteminde parametre olarak birinci gizli katmanda s1rası ile [30-20-10] değerleri, ikinci gizli katmanda ise sırası ile [10-8-4] değerleri kullanılmıştır. Çıkış katmanında ise çıktı olarak elektrik tüketimi GWh cinsinden yer almaktadır. 2023 yılına kadar yapılan tahminlerde de bu YSA modeli kullanılmıştır. YSA modelinin testi için hata kriteri olarak ortalama karesel hataların karekökü (OKHK), ortalama mutlak yüzde hata (OMYH) ve belirleme katsayısı $\left(\mathrm{R}^{2}\right)$ kullanılmış olup Denklem (1)'de OKHK, Denklem (2)'de OMYH ve Denklem (3)’te $\mathrm{R}^{2}$ formülleri verilmiştir.

$$
O K H K=\sqrt{\frac{1}{n} \sum_{i=1}^{n}\left(Z_{i}-\hat{Z}_{i}\right)^{2}}
$$

Denklem (1)'de $Z$ hedeflenen elektrik değerini, $\hat{Z}$ ise bulunan elektrik tüketimi değerini ifade etmekte olup, $n$ ise örnek sayısıdır.

$$
O M Y H=\left(\frac{1}{n} \sum_{i=1}^{n} \frac{\left|Z_{i}-\widehat{Z}_{l}\right|}{\left|Z_{i}\right|}\right) * 100
$$

Denklem (2)'de OMYH formülü verilmiş olup $Z$ hedeflenen elektrik değerini, $\hat{Z}$ ise bulunan elektrik tüketimi değerini, $n$ ise örnek sayısını ifade etmektedir. OMYH, hatanın boyutunu yüzde olarak ölçmektedir.

$$
R^{2}=1-\frac{\sum_{i=1}^{n}\left(Z_{i}-\widehat{Z}_{l}\right)^{2}}{\sum_{i=1}^{n}\left(Z_{i}-\bar{Z}_{i}\right)^{2}}
$$

Denklem (3)'te $Z$ hedeflenen elektrik değerini, $\hat{Z}$ bulunan elektrik tüketimi değerini, $\bar{Z}$ hedeflenen elektrik değerinin ortalamasını, $n$ ise örnek sayısını ifade etmektedir.

YSA modelinin eğitimi için geriye yayılım yöntemlerinden ölçeklendirilmiş eşleştirmeli gradyent, Levenberg-Marquardt ve Bayes düzenleme yöntemi gibi algoritmalar mevcuttur. Bunlardan ölçeklendirilmiş eşleştirmeli gradyent yöntemi, doğrudan arama süresini kısaltmak için geliştirilmiş ve güvenilir bölgelerin birleştirilmesine dayanan bir algoritmadır (Moller 1993). Levenberg-Marquardt algoritması, maksimum komşuluk yapısını baz alan bir en küçük kareler hesaplama yöntemi olup Gauss-Newton ve en dik iniş algoritmalarının en iyi 
özelliklerini birleştirip bu iki metodun kısıtlamalarını kaldırmaktadır (Kayabasi, 2015). Bayes düzenleme yöntemi ise, ağırlık ve bias değerlerini Levenberg Marquardt yöntemini kullanarak güncelleştirir. Karesel hata ve ağırlıkların kombinasyonu içeren Denklem (4)'teki ifadeyi minimize etmeye ve ağı oluşturmak için doğru kombinasyonu belirlemeye çalışır (Mackay, 1992; Foresee ve Hagan, 1997).

$$
F=\beta \sum_{i=1}^{n}\left(Z_{i}-\hat{Z}_{i}\right)^{2}+\alpha \sum_{i, j}\left\|w_{i j}\right\|^{2}
$$

Denklem (4)'te $Z$ hedeflenen değeri, $\hat{Z}$ ise tahmin edilen değeri ifade etmekte olup, w ise ağırlıkları ifade edip tüm ağ ağırlıklarının toplamının karesi hesaplanmaktadır. $\beta$ ve $\alpha$ ise kontrol parametreleri olup bunların en uygun değeri alması modelin genelleştirilmesini sağlamaktadır.

Ağın eğitilmesinde en büyük problemlerin başında gelen aşırı öğrenme (overfitting) sorunu için düzenleme (regülâsyon) teknikleri kullanılarak bu sorunun üstesinden gelinebilmektedir. Düzenleme algoritmaları, ağırlık değerlerinin daha küçük değerlerde kalması için ağı zorlarlar. Bu ağın cevabının daha yumuşak olmasına ve ağın ezberleme olasılığının düşmesini sağlamaktadır. Bayes düzenleme (Bayesian Regularization) yöntemi de ağ mimarisinin yanı sıra uygunluk durumunu da dikkate alarak aşırı öğrenme sorununu en aza indirmektedir (Okut, 2016; Burden ve Winkler, 2008; Doan ve Liong, 2004).

$\mathrm{Bu}$ çalışmada veri seti farklı yapıda öznitelikler içermek yerine sadece zamana bağlı olduğu için eğitim sırasında aşırı öğrenme sorunu ortaya çıkabilmektedir. Bu sebeple daha önceden de belirtildiği gibi bu sorunu en aza indirebilen bir algoritma olan Bayes düzenleme yöntemi bu çalışmada tercih edilmiştir.

YSA'nın testi yani 1970-2016 yıllarına ait mevcut verilere ait tahmin yapmak ve bir model ortaya koymak için birisi-dışarıda çapraz doğrulama yöntemi kullanılmıştır. Çapraz doğrulama, öğrenicinin daha önce görmediği veriler için yeni tahminler yapması istenildiğinde ne kadar iyi tahmin yapabileceğinin bir göstergesi olabilen bir model değerlendirme yöntemidir. Fakat eğitim sürecinde eldeki tüm veri seti eğitim için kullanılırsa öğrenici bunu ezberleyip aynı değerler için mükemmel sonuçlar tahmin etse de hiç görmediği bir veri için ne sonuç üreteceği bilinemeyecektir. Bu problem aşırı öğrenme (overfitting) olarak bilinmekte olup bunun üstesinden gelmek için, bir öğrenici eğitimi yapılırken tüm veri seti eğitim için kullanılmamalı bir kısmı öğrenicinin hiç görmediği verileri oluşturan test verisi olarak kullanılmalıdır. Bu yöntemin düşüncesi, öğrenici üzerinde en iyi parametreler kombinasyonu 
bulunduğunda, bu parametrelerin performansını farklı veriler ile test etmektir. Fakat veri setinde yer alan örnek sayısı az olduğunda bunları k-kat çapraz doğrulama ile ayrıştırmak zor olup istatistiki olarak uygun sonuçlar vermez. Bu sebeple, özellikle 100'ün altında örnek içeren küçük veri setlerinde birisi-dışarıda çapraz doğrulama yöntemi kullanılmaktadır (Yadav ve Shukla, 2016; Pasini, 2015; Wong, 2015; Krishna vd., 2012). Birisi-dışarıda çapraz doğrulama yönteminde test seti olarak sadece bir örnek alınıp, veri setinde geriye kalan tüm örnekler eğitim seti olarak kullanılmakta olup Şekil 5'te bu yapı görülmektedir. Eğitim seti, modelin performansını bu tek örnekteki hatayı bulmak için kullanılır. Bu işlem mevcut veri setindeki örneklerin her biri için tekrarlanır, modelin hatası da sonuçların ortalaması alınarak bulunur (Ambroise ve McLachlan, 2002).

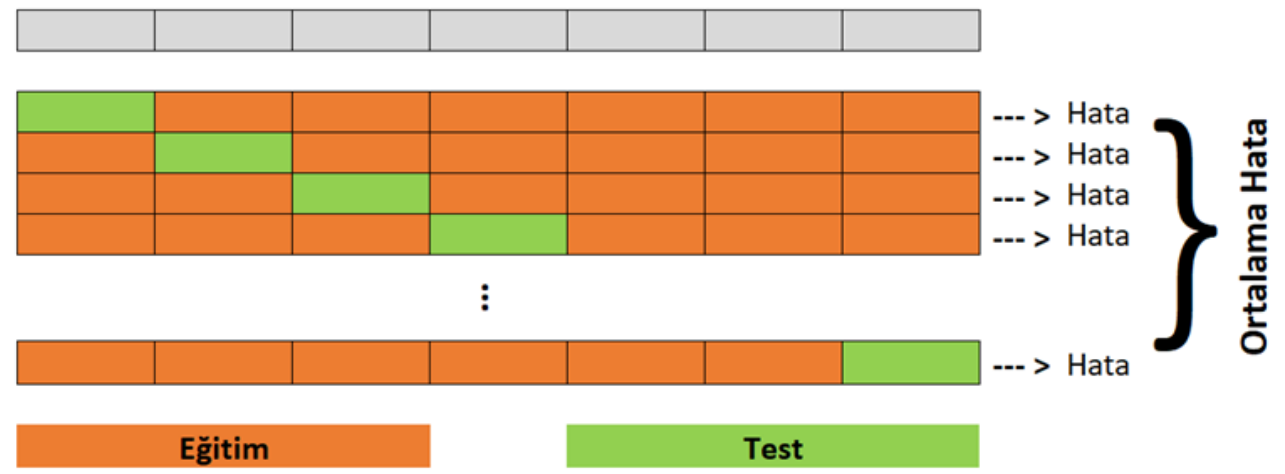

Şekil 5. Birisi-dışarıda çapraz doğrulama yöntemi

Şekil 5'te görülen çapraz doğrulama yöntemi genellikle örneklem sayısı az olan veri setlerinde kullanılmaktadır. Her bir örnek kendini test verisi olarak kullandığı için aşırı büyük veri setleri için de performans açısından uygun değildir.

\section{BULGULAR}

2017-2023 yıllarına ait sanayi elektrik tüketimi tahmini için kullanılacak YSA modeline ait en uygun parametreleri belirlemek amacıyla gizli katmanlarda çeşitli sayıda nöron grid arama yöntemi ile denenmiştir. İterasyon sayısının 1000 olarak sabit tutulduğu YSA'da eğitim ve test amaciyla kullanılan veri setini, TUİK'in (TUİK, 2018) yayınladığı 1970-2016 yıllarındaki elektrik tüketiminin ölçeklendirilmiş hali oluşturmakta olup modelin başarısı için birisi-dışarıda çapraz doğrulama yöntemi kullanılmıştır. Bu süreçte eğitim 5 kez tekrarlanıp minimum, maksimum, ortalama ve standart sapma değerlerine bakılmıştır. Daha sonra elde edilen değerlerden yola çıkılarak en uygun parametreler belirlenip ileriye yönelik tahminleme gerçekleştirilmiştir. 


\subsection{TUİK Verilerine İlişkin Bulgular ve En Uygun YSA Parametrelerinin Belirlenmesi}

1970-2016 yılları arasındaki 47 adet ölçeklendirilmiş TUİK verileri kullanılarak YSA eğitilip test edilmiştir. Çeşitli nöron sayıları ile gerçekleştirilen testler sonucunda en iyi YSA parametreleri belirlenmeye çalışılmış olup iterasyon sayısı sabit kabul edilip 1000 olarak belirlenmiştir. Modelin başarısı için $5 \mathrm{kez}$ tekrarlanan test sürecinde, test seti için Denklem (1)'de verilen OKHK hata değerine ilişkin minimum, maksimum, ortalama ve standart sapma değerleri Tablo 2'de görülmektedir.

Tablo 2. Farklı nöron sayıları için 1970-2016 yıllarına ait OKHK sonuçları

\begin{tabular}{|c|c|c|c|c|c|}
\hline \multicolumn{2}{|c|}{ Gizli Katman Nöron Sayıları } & \multicolumn{4}{|c|}{ Test Setine İlişkin OKHK Değerleri } \\
\hline 1. Katman & 2. Katman & Ortalama & Minimum & Maksimum & $\begin{array}{c}\text { Standart } \\
\text { Sapma }\end{array}$ \\
\hline 30 & 10 & 10.27 & 8.40 & 11.75 & 1.21 \\
\hline 30 & 8 & 12.56 & 10.16 & 13.88 & 1.59 \\
\hline 30 & 4 & 21.65 & 19.40 & 24.30 & 2.14 \\
\hline 20 & 10 & 8.58 & 6.12 & 10.97 & 1.80 \\
\hline 20 & 8 & 8.99 & 7.08 & 11.21 & 1.52 \\
\hline 20 & 4 & 20.78 & 19.54 & 22.05 & 0.99 \\
\hline 10 & 10 & 9.37 & 7.62 & 11.11 & 1.65 \\
\hline 10 & 8 & 11.59 & 9.08 & 14.00 & 2.36 \\
\hline 10 & 4 & 22.39 & 20.63 & 24.73 & 1.90 \\
\hline
\end{tabular}

Tablo 2'de de görüldüğü gibi 1. gizli katmanda 20 nöron ve 2. gizli katmanda 10 ve 8 nöron kullanımı ortalama hata olarak sırasıyla 8.58 ve 8.99 değerlerini vermiş olup en düşük değerler olarak görülmektedir. Bu iki değer birbirine yakın olup standart sapma değerleri incelendiğinde 1.52 değeri ile 2. gizli katmanda 8 nöronun kullanımı daha stabil gözükmektedir. Test seti için Denklem (2)'de verilen OMYH hata değerine ilişkin minimum, maksimum, ortalama ve standart sapma değerleri Tablo 3'te görülmektedir.

Tablo 3. Farklı nöron sayıları için 1970-2016 yıllarına ait OMYH sonuçları

\begin{tabular}{|c|c|c|c|c|c|}
\hline \multicolumn{2}{|c|}{ Gizli Katman Nöron Sayıları } & \multicolumn{3}{|c|}{ Test Setine İlişkin OMYH Değerleri (\%) } \\
\hline 1. Katman & 2. Katman & Ortalama & Minimum & Maksimum & $\begin{array}{c}\text { Standart } \\
\text { Sapma }\end{array}$ \\
\hline 30 & 10 & 38.98 & 23.35 & 63.96 & 19.68 \\
\hline 30 & 8 & 44.42 & 35.04 & 52.26 & 6.27 \\
\hline 30 & 4 & 87.86 & 75.99 & 99.18 & 10.29 \\
\hline 20 & 10 & 31.25 & 18.79 & 48.51 & 12.12 \\
\hline 20 & 8 & 31.60 & 19.93 & 43.05 & 10.07 \\
\hline 20 & 4 & 83.74 & 79.83 & 93.61 & 5.61 \\
\hline 10 & 10 & 32.06 & 20.77 & 44.51 & 12.53 \\
\hline 10 & 8 & 60.18 & 38.90 & 78.17 & 16.04 \\
\hline 10 & 4 & 107.32 & 99.95 & 119.80 & 7.64 \\
\hline
\end{tabular}


Tablo 3'e göre 1. gizli katmanda 20 nöron ve 2. gizli katmanda 10 ve 8 nöron kullanımı ortalama OMYH hatası olarak sırasıyla \%31.25 ve \%31.60 değerlerini vermiş olup en düşük değerler olarak görülmektedir. Bu iki değer birbirine yakın olup standart sapma değerleri incelendiğinde 10.07 değeri ile 2. gizli katmanda 8 nöronun kullanımı yine daha stabil gözükmektedir.

Denklem (3)'e göre $\mathrm{R}^{2}$ sonuçları değerlendirildiğinde birisi-dışarıda çapraz doğrulama yöntemi kullanıldığı için test setinde tek bir örnek yer almakta olup, buna ait hata değeri hesaplanırken bölen sıfır olduğu için sonuç sonsuz (inf) olmaktadır. Bu sebeple Tablo 4 'te tüm test setine ait $\mathrm{R}^{2}$ değerlerine yer verilmiştir.

Tablo 4. Farklı nöron sayıları için 1970-2016 yıllarına ait R² sonuçları

\begin{tabular}{|c|c|c|c|c|c|}
\hline \multicolumn{2}{|c|}{ Gizli Katman Nöron Sayıları } & \multicolumn{4}{|c|}{ Tüm Test Setine İlişkin $\mathbf{R}^{2}$ Değerleri } \\
\hline 1. Katman & 2. Katman & Ortalama & Minimum & Maksimum & $\begin{array}{c}\text { Standart } \\
\text { Sapma }\end{array}$ \\
\hline 30 & 10 & 0.93 & 0.89 & 0.94 & 0.05 \\
\hline 30 & 8 & 0.90 & 0.85 & 0.91 & 0.03 \\
\hline 30 & 4 & 0.52 & 0.43 & 0.54 & 0.03 \\
\hline 20 & 10 & 0.95 & 0.91 & 0.96 & 0.03 \\
\hline 20 & 8 & 0.94 & 0.92 & 0.96 & 0.02 \\
\hline 20 & 4 & 0.58 & 0.49 & 0.65 & 0.06 \\
\hline 10 & 10 & 0.91 & 0.85 & 0.96 & 0.04 \\
\hline 10 & 8 & 0.68 & 0.61 & 0.82 & 0.08 \\
\hline 10 & 4 & 0.35 & 0.21 & 0.49 & 0.10 \\
\hline
\end{tabular}

Tablo 4 incelendiğinde 1. gizli katmanda 20 nöron ve 2. gizli katmanda 10 ve 8 nöron kullanımı $\mathrm{R}^{2}$ değerleri sırasıyla 0.95 ve 0.94 değerlerini vermiştir. Bu değerler yine birbirine yakın değerlendirilip standart sapma değerleri incelendiğinde 0.02 değeri ile 2. gizli katmanda 8 nöronun kullanımının Tablo 2 ve Tablo 3'teki gibi yine daha stabil olduğu görülmektedir. Orijinal veriye karşılık test sonuçlarına ilişkin eğri Şekil 6'da görülmektedir.

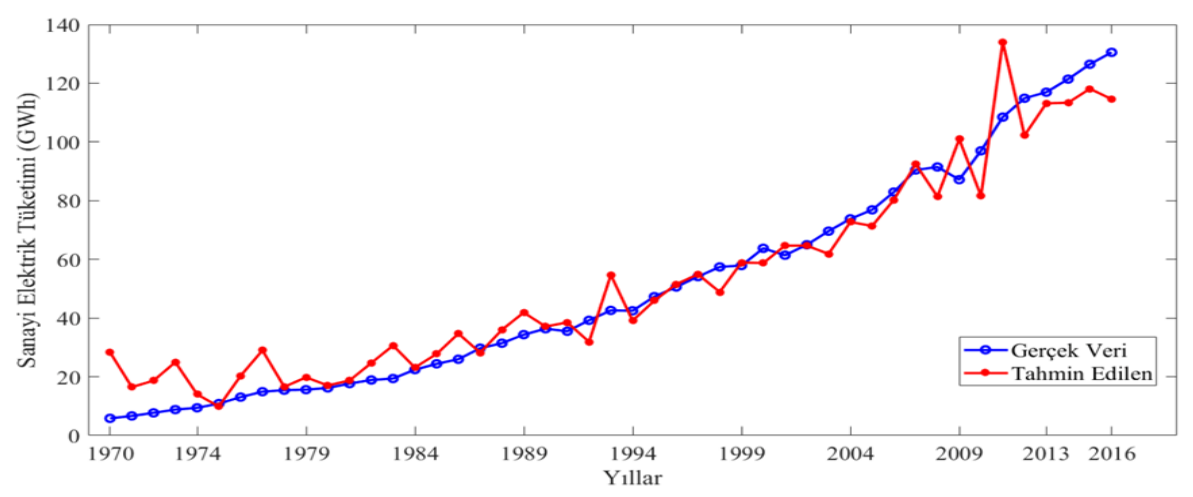

Şekil 6. En uygun parametreler ile 1970-2016 yıllarına ait YSA tahmin sonuçları 
Şekil 6'da kullanılan YSA modeli, Tablo [2-4]'e göre elde edilen en iyi parametrelerden iterasyon sayısı 1000, 1. gizli katman nöron sayısı 20 ve 2. gizli katman nöron sayısı 8 için oluşturulmuştur. Şekil 6' da da görüldüğü gibi YSA ile elde edilen sonuçlar orijinal verileri takip edebilmiş olup geliştirilen modelin başarılı bir şekilde sanayi alanında kullanılan elektrik tüketimini tahmin edebildiği görülmüştür. Aynı parametrelere sahip model daha sonra 20172023 yıllarına ait sanayi elektrik tüketimi içinde kullanılmıştır.

Ülkelerin gelişmişliklerinin sanayileri ile ölçüldüğ̈ günümüzde Endüstri 4.0 devriminin de gittikçe yaygınlaşmasıyla birlikte sanayiye olan ihtiyaç daha da artmaktadır. $\mathrm{Bu}$ sebeple Türkiye'nin ileriki yıllarda enerji ihtiyacına düşmemesi için geleceği planlayıp bu tüketim ihtiyaçlarına uygun yeni enerji projeleri geliştirmesi gerekmektedir. Elde edilen sonuçlar sanayi alanında elektrik tüketiminin tahmin edilebilmesine imkân tanımış olup bu modelin ileriye yönelik tahminlemede de kullanılabileceğini göstermiştir. $\mathrm{Bu}$ sayede bir taraftan sanayide gelişilirken bir taraftan da bu gelişime paralel olarak ortaya çıkacak elektrik tüketimi kontrol altında tutulabilecektir.

\subsection{7-2023 yıllarını kapsayan sanayi elektrik tüketiminin YSA ile tahmini}

Geleceğe yönelik tahminleme kişi ve kurumlara işlerini daha gerçekçi programlama imkânı tanırken bu yönde oluşacak ihtiyaçlara da kendilerini daha önceden hazırlama imkânı sunmaktadır. Bu sebeple Şekil 6'da görülen başarılı model 2017-2023 yıllarına ait sanayi alanındaki elektrik tüketimini tahmin etmek için de kullanılmıştır. TEİAŞ'ın raporunda da kendilerine ait tahmin değerleri yer almakta olup elektrik enerjisi üretimi için şu an başlayan ve gelecekte başlatılacak santraller ile bu ihtiyacın kapanıp kapanamayacağını göstermişlerdir. TEİAŞ elektrik enerjisi talep tahmini yaparken Türkiye'ye ait elektrik sistemini dikkate alıp brüt talebi vermiştir. Bu ihtiyaca iletim ve dağıtım hatlarındaki kayıplar ve kaçak ile enerji santrallerinin kendi elektrik ihtiyaçları da dahil edilmiştir. Bu çalışmada bu verilerin minimum ihtiyaç için olan kısımlarından sanayi alanında ölçeklenmiş payı kullanılmıştır.

Bu çalışmada, TEİAŞ'a ait tahminler ile YSA modeline ait tahmin değerleri birbirleri ile karşılaştırılmış olup hata değeri bulunurken Denklem (1-3)'ten yararlanılmış olup, hedef veriler olarak TEİAŞ tahminleri kullanılmıştır. Yine önceki modelde olduğu gibi 5 kez tekrarlanan YSA eğitiminde test verisi olan 2017-2023 y1llarına ait sanayi elektrik tüketimi tahmin değerleri Şekil 7'de görülmektedir. 


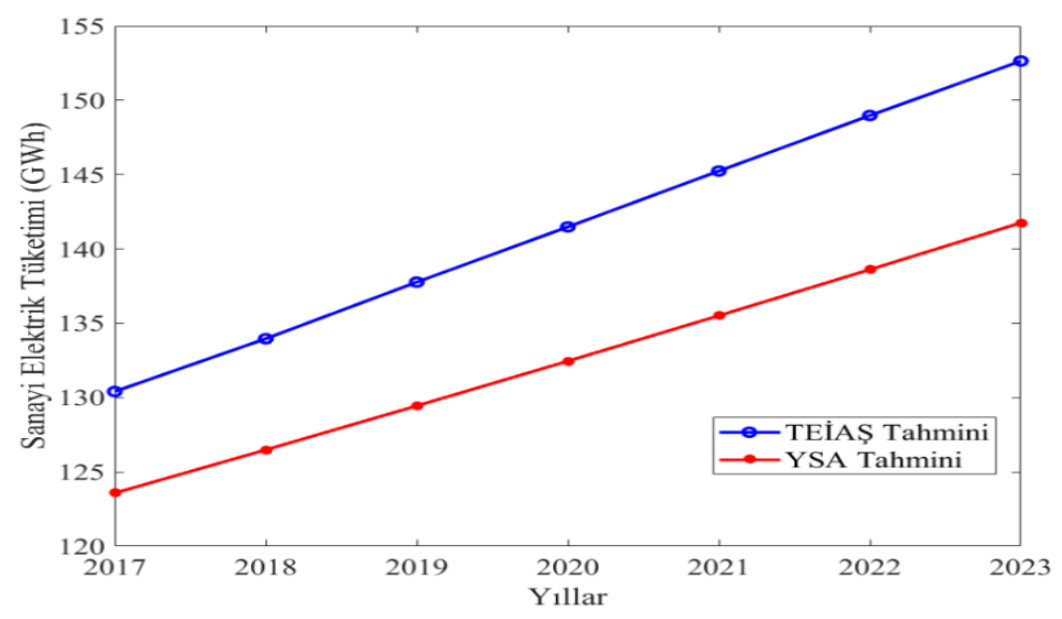

Şekil 7. 2017-2023 yıllarına ait YSA değerleri ile TEİAŞ tahminlerinin karşılaştırılması

Şekil 7'de verilen YSA sonuçlarına ait ortalama hata, minimum, maksimum ve standart sapma değerleri sırasıyla OKHK kriteri için 10.76, 7.32, 12.84 ve 2.25 olarak, OMYH için \%8.29, \%6.19, \%9.29 ve 3.23 olarak, $\mathrm{R}^{2}$ için ise $0.52,0.48,0.54$ ve 0.02 olarak bulunmuş olup bu değerler TEİAŞ tahminleri ile karşılaştırılarak hesaplanmıştır. YSA tahminleri ile TEİAŞ'a ait tahmin değerleri birbirine paralellik göstermekte olup bir miktar farklılık içermektedir. TEİAŞ'ın 2000 yılından sonra her yıl yaptığı tahminler incelendiğinde yıllara göre farklı olmakla birlikte \%0.4 ile \%52.3 oranında sapma olabildiği görülmektedir (TEİAŞ, 2018). Dolayısıyla hangi tahmin değerlerinin gelecekte gerçekleşeceği kesin olarak bilinememektedir. Fakat her iki tahmininde ortak yanı paralel bir şekilde elektrik tüketiminin artacağını öngörmeleridir. TEİAȘ ve YSA'nın 2023 yılına kadarki tahminleri ve aralarındaki fark Tablo 5'te verilmiştir.

Tablo 5. 2017-2023 yıllarına ait TEİAŞ ve YSA elektrik tüketimi tahminleri (GWh)

\begin{tabular}{|c|c|c|c|}
\hline Yıl & TEİAS & YSA & Fark (\%) \\
\hline $\mathbf{2 0 1 7}$ & 130.4 & 123.6 & 5.21 \\
\hline $\mathbf{2 0 1 8}$ & 134.0 & 126.5 & 5.60 \\
\hline $\mathbf{2 0 1 9}$ & 137.8 & 129.4 & 6.10 \\
\hline $\mathbf{2 0 2 0}$ & 141.5 & 132.5 & 6.36 \\
\hline $\mathbf{2 0 2 1}$ & 145.2 & 135.5 & 6.68 \\
\hline $\mathbf{2 0 2 2}$ & 149.0 & 138.6 & 6.98 \\
\hline $\mathbf{2 0 2 3}$ & 152.6 & 141.8 & 7.08 \\
\hline
\end{tabular}


Tablo 5'e göre TEİAŞ elektrik tüketiminin daha hızlı artacağını öngörmekte olup YSA ile aralarındaki fark yıllara göre artmaktadır. Şekil 8'de 1970-2016 arası TEİAŞ ve YSA tahminleriyle 2017-2023 arası tahminler birlikte görülmektedir.

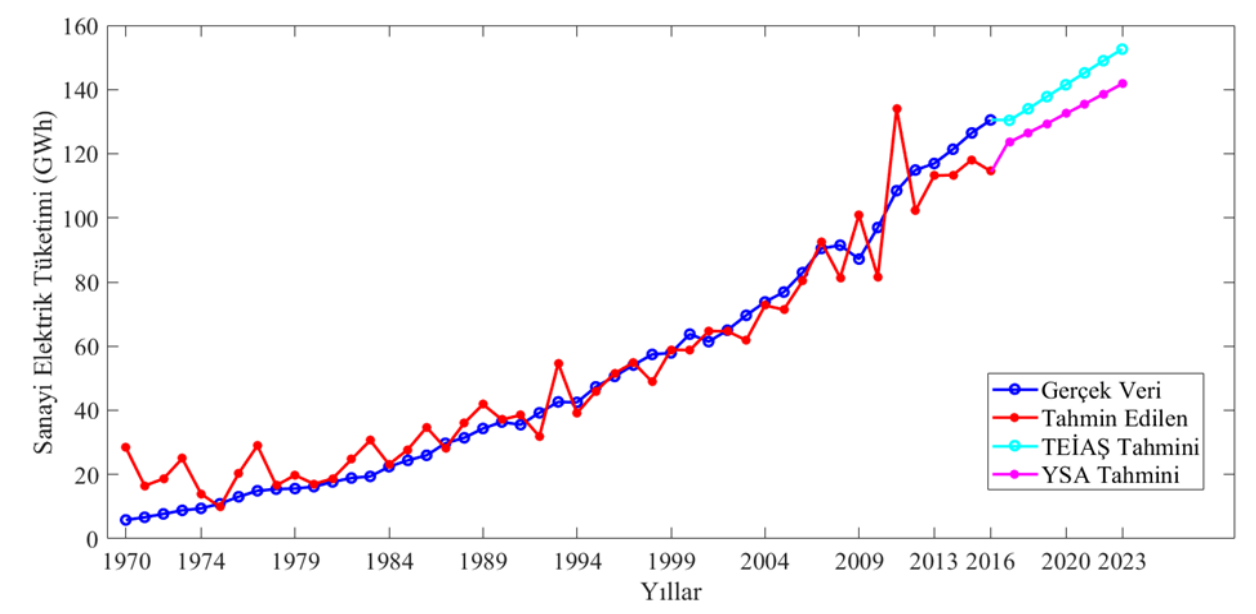

Şekil 8. 1970-2023 yıllarına ait TUIK, YSA ve TEİAŞ verilerinin karşılaştırılması

Şekil 8'de de görüldüğü gibi YSA tahminleri TUİK ve TEİAŞ verilerine paralellik göstermektedir. TEİAŞ'ın kendi raporunda belirttiği her iki senaryoda da olduğu gibi mevcut ve gerçekleşmekte olan projeler de göz önüne alınarak 2017-2021 dönemine ait 5 yıllık süreç boyunca enerji talebinin yeterli yedekle karşılanabileceği öngörülmektedir. YSA'nın tahminleri bu değerlerin biraz daha az olacağı yönünde olup yine yeterli yedek ile talebin karşılanabileceğini göstermektedir. Bu bulgular ile Türkiye'nin mevcut şartlar ile elektrik üretim ve tüketiminde ileriki yıllarda sıkıntıya düşmeyeceği öngörülmüştür.

\section{SONUÇ VE TARTIŞMA}

Sanayinin gelişimi, ülkelerin gelişmişlikleri ve birbirlerine karşı güçleriyle yüzyıllardır hep ilişkili olmuştur. Ülkelerin gelecek planlarında sanayilerine ait üretim ve tüketim değerlerini öngörmeleri avantajlarına olacak olup daha sağlıklı projeler geliştirmelerine olanak tanıyacaktır.

Bu çalışmada Türkiye'de 1970-2016 dönemi için yıllık sanayi alanındaki elektrik tüketimi değerlerini içeren 47 adet veri kullanılarak ileri beslemeli YSA modeli Bayes Düzenleme öğrenme algoritması ile 1000 iterasyon üzerinden eğitilmiştir. Grid arama tekniği ile en iyi gizli katman nöron sayılarının sırası ile 20 ve 8 olarak bulunduğu model, OKHK değeri olarak 8.99, OMYH değeri olarak \%31.60 ve $\mathrm{R}^{2}$ değeri olarak ta 0.94 sonuçlarını vererek başarı 
ile oluşturulmuştur. Daha sonra aynı model ile 2017-2023 yıllarına ait elektrik tüketim miktarları Gigawatt Saat (GWh) cinsinden tahmin edilmiştir.

Gerçekleştirilen sanayi alanındaki elektrik tüketimine ilişkin tahminleme ile günümüze kadarki verilerde iyi sonuçlar elde edilebilmiş ve bu YSA modeli gelecek tahmini için de kullanılabilmiştir. Öngörülen değerlerin TEİAŞ tahminlerine göre ortalama OKHK için 10.76, OMYH için \%8.29, $\mathrm{R}^{2}$ için ise 0.52 değerleri göz önüne alındığında çok yüksek çıkmaması ve paralellik göstermesi sebebiyle yeterli yedekle birlikte Türkiye'nin ileriki dönemde enerji talebinin karşılanabileceği düşünülmektedir.

Bu çalışmada elde edilen 2023 yllana kadarki tüketim tahminleri Türkiye'nin gelecek yıllardaki enerji ihtiyacını karşılamak için geliştirdiği veya ileride planladığı projeler için de faydalı olup referans noktası olabilecektir. Ülkelerin gelişimiyle birlikte tüketim değerlerinin de arttığı göz önüne alındığında tahminleme ile bu problem bir nebze kontrol edilebilecektir. Bunun yanında sanayi alanındaki değerlerin tahmin edilmesi ile de bu alandaki çalışmalara ait boşluk bir nebze doldurulmuştur.

Elde edilen bulgular ile çıkarılabilecek sonuçlardan bir diğeri de tahmin edilebilen ve ileriki yıllarda artacak olan elektrik tüketimini karşılayabilecek gücün hangi kaynaktan karşılanması durumudur. Sanayi alanındaki elektrik ihtiyacının karşılanmasında sıkıntıya düşülmemesi için ilgili projeler göz ününe alındığında Şekil 2'de verilen ve ileriki yıllarda oranı artacak olan güneş enerjisinden yararlanılmalı ve bu kaynaktan pay alınmalıdır. Bu sebeple mevcut ve yeni üretilecek sanayi tesislerinin mimarisinde güneş enerjisinin kullanımına yönelik planlamaların yapılması uzun vadede faydalı olacaktır.

İleriki çalışmalarda, ihracat ile buna doğrudan etkisi olan sanayinin birbirleri ile ilişkilerinin incelenmesi amaçlanmaktadır. Bu sayede sanayi elektrik enerjisi tüketimiyle ihracat rakamlarının tahmini yapılıp bu değerlerin Türkiye'nin 2023 hedefleri ile örtüşüp örtüşmedikleri görülebilecektir.

\section{REFERENCES / KAYNAKLAR}

Adom, P. K. \& Bekoe, W. (2012). Conditional dynamic forecast of electrical energy consumption requirements in Ghana by 2020: a comparison of ARDL and PAM. Energy, 44(1), 367-380. 


\section{Pençe, I., Kalkan, A. \& Şişeci Çeşmeli, M.}

Ahmad, A. S., Hassan, M. Y., Abdullah, M. P., Rahman, H. A., Hussin, F., Abdullah, H. \& Saidur, R. (2014). A review on applications of ANN and SVM for building electrical energy consumption forecasting. Renewable and Sustainable Energy Reviews, 33, 102-109.

Akay, D. \& Atak, M. (2007). Grey prediction with rolling mechanism for electricity demand forecasting of Turkey. Energy, 32(9), 1670-1675.

Akyılmaz, O. \& Ayan, T. (2006). Esnek hesaplama yöntemlerinin jeodezide uygulamaları. İTÜ Dergisi, 5(1), 261268.

Amber, K. P., Aslam, M. W. \& Hussain, S. K. (2015). Electricity consumption forecasting models for administration buildings of the UK higher education sector. Energy and Buildings, 90, 127-136.

Ambroise, C. \& McLachlan, G.J. (2002). Selection bias in gene extraction on the basis of microarray geneexpression data. Proc. Nat. Acad. Sci. USA, 99(10), 6562-6566.

Arisoy, I. \& Ozturk, I. (2014). Estimating industrial and residential electricity demand in Turkey: A time varying parameter approach. Energy, 66, 959-964.

Arslan, A. \& İnce, R. (1996). The Neural network approximation to the size effect in fracture of cemetitious materials. Engineering Fracture Mechanics, 54(2), 249-261.

Aydoğdu, G. \& Yildiz, O. (2017). Forecasting the annual electricity consumption of Turkey using a hybrid model. IEEE 25th Signal Processing and Communications Applications Conference (SIU), 1-4.

Babich, L., Svalov, D., Smirnov, A. \& Babich, M. (2019). Industrial power consumption forecasting methods comparison. In 2019 Ural Symposium on Biomedical Engineering, Radioelectronics and Information Technology (USBEREIT), IEEE, 307-309.

Balcı, H., Esener, İ. I. \& Kurban, M. (2012). Regresyon analizi kullanılarak kısa dönem yük tahmini. ElektrikElektronik ve Bilgisayar Mühendisliği Sempozyumu, 796-801.

Barak, S. \& Sadegh, S. S. (2016). Forecasting energy consumption using ensemble ARIMA-ANFIS hybrid algorithm. International Journal of Electrical Power \& Energy Systems, 82, 92-104.

Başoğlu, B. \& Bulut, M. (2017). Kısa dönem elektrik talep tahminleri için yapay sinir ağları ve uzman sistemler tabanlı hibrid tahmin sistemi geliştirilmesi. Gazi Üniversitesi Mühendislik-Mimarlık Fakültesi Dergisi, 32(2), 575583.

Bayramoğlu, T., Pabuçcu, H. \& Boz, F. Ç. (2017). Türkiye için anfis modeli ile birincil enerji talep tahmini. Ege Akademik Bakis, 17(3), 431-445.

Behrang, M. A., Assareh, E., Assari, M. R. \& Ghanbarzadeh, A. (2011). Assessment of electricity demand in Iran's industrial sector using different intelligent optimization techniques. Applied Artificial Intelligence, 25(4), $292-304$.

Bianco, V., Manca, O. \& Nardini, S. (2009). Electricity consumption forecasting in Italy using linear regression models. Energy, 34(9), 1413-1421.

Bianco, V., Manca, O. \& Nardini, S. (2013). Linear regression models to forecast electricity consumption in Italy. Energy Sources, Part B: Economics, Planning, and Policy, 8(1), 86-93.

Bilgili, M., Sahin, B., Yasar, A. \& Simsek, E. (2012). Electric energy demands of Turkey in residential and industrial sectors. Renewable and Sustainable Energy Reviews, 16(1), 404-414.

Biricik, G., Bozkurt, Ö. Ö. \& Tayşi, Z. C. (2015). Analysis of features used in short-term electricity price forecasting for deregulated markets. IEEE 23th Signal Processing and Communications Applications Conference (SIU), 600-603.

Boltürk, E. (2013). Elektrik talebi tahmininde kullanılan yöntemlerin karşılaştırılması (Yüksek lisans tezi). İstanbul Teknik Üniversitesi, Fen Bilimleri Enstitüsü, İstanbul. 


\section{MAKÜ-Uyg. Bil. Derg., 3(2), 206-228, 2019}

Burden, F. \& Winkler, D. (2008). Bayesian regularization of neural networks. In Artificial neural networks, Humana Press, 23-42.

Cabral, J. D. A. Legey, L. F. L. \& Freitas Cabral, M. V. D. (2017). Electricity consumption forecasting in Brazil: A spatial econometrics approach. Energy, 126, 124-131.

Cao, G. \& Wu, L. (2016). Support vector regression with fruit fly optimization algorithm for seasonal electricity consumption forecasting. Energy, 115, 734-745.

Chae, Y. T., Horesh, R., Hwang, Y. \& Lee, Y. M. (2016). Artificial neural network model for forecasting subhourly electricity usage in commercial buildings. Energy and Buildings, 111, 184-194.

Chou, J. S., Hsu, S. C., Ngo, N. T., Lin, C. W. \& Tsui, C. C. (2019). Hybrid machine learning system to forecast electricity consumption of smart grid-based air conditioners. IEEE Systems Journal, 13(3), 3120-3128

Çalık, A. E. \& Şirin, H. (2017). Türkiye'deki elektrik enerji ihtiyacının matematiksel bir modellemesi. Sakarya University Journal of Science, 21(6), 1475-1482.

Demirel, Ö., Kakilli, A. \& Tektaş, M. (2010). Anfis ve arma modelleri ile elektrik enerjisi yük tahmini. Gazi Üniversitesi Mühendislik-Mimarlık Fakültesi Dergisi, 25(3), 601-610.

Dilaver, Z. \& Hunt, L. C. (2011). Industrial electricity demand for Turkey: a structural time series analysis. Energy Economics, 33(3), 426-436.

Doan, C. D. \& Liong, S. Y. (2004). Generalization for multilayer neural network bayesian regularization or early stopping. In Proceedings of Asia Pacific Association of Hydrology and Water Resources 2nd Conference.

Dong, B., Li, Z., Rahman, S. M. \& Vega, R. (2016). A hybrid model approach for forecasting future residential electricity consumption. Energy and Buildings, 117, 341-351.

Eke, İ. (2011). Diferansiyel evrim algoritması destekli yapay sinir ağı ile orta dönem yük tahmini. Uluslararası Mühendislik Araştırma ve Geliştirme Dergisi, 3(1), 28-32.

Ekonomou, L. (2010). Greek long-term energy consumption prediction using artificial neural networks. Energy, $35(2), 512-517$

Enerji Piyasası Düzenleme Kurumu (EPDK). Erişim tarihi: 21.03.2018, https://www.epdk.org.tr/Detay/Icerik/30-24/elektrikyillik-sektor-raporu

Enerji ve Tabii Kaynaklar Bakanlı̆̆l (ETKB). Erişim tarihi: 21.03.2018, http://www.enerji.gov.tr/trTR/Sayfalar/Elektrik

Fırat, Ö. \& Güngör, M. (2004). Askı madde konsantrasyonu ve miktarının yapay sinir ağları ile belirlenmesi. $\dot{I M O}$ Teknik Dergi, 219, 3267-3282.

Foresee, F. D. \& Hagan, M. T. (1997). Gauss-Newton approximation to Bayesian learning. Proceedings of the International Joint Conference on Neural Networks, 3, 1930-1935.

Goodfellow, I., Bengio, Y. \& Courville, A. (2016). Deep learning. Cambridge, MA: MIT Press.

Gürbüz, F., Öztürk, C. \& Pardalos, P. (2013). Prediction of electricity energy consumption of Turkey via artificial bee colony: A case study. Energy Systems, 4(3), 289-300.

Hamzaçebi, C. (2007). Forecasting of Turkey's net electricity energy consumption on sectoral bases. Energy Policy, 35(3), 2009-2016.

Hamzaçebi, C. \& Kutay, F. (2004). Yapay sinir ağlari ile Türkiye elektrik enerjisi tüketiminin 2010 yılına kadar Tahmini. Gazi Üniversitesi Mühendislik-Mimarlık Fakültesi Dergisi, 19(3), 227-233. 


\section{Pençe, I., Kalkan, A. \& Şişeci Çeşmeli, M.}

Hu, Y. C. (2017). Electricity consumption prediction using a neural-network-based grey forecasting approach. Journal of the Operational Research Society, 68(10), 1259-1264.

Hussain, A., Rahman, M. \& Memon, J. A. (2016). Forecasting electricity consumption in Pakistan: The way forward. Energy Policy, 90, 73-80.

Jain, R. K., Smith, K. M., Culligan, P. J. \& Taylor, J. E. (2014). Forecasting energy consumption of multi-family residential buildings using support vector regression: Investigating the impact of temporal and spatial monitoring granularity on performance accuracy. Applied Energy, 123, 168-178.

Karaca, C. \& Karacan, H. (2016). Çoklu regresyon metoduyla elektrik tüketim talebini etkileyen faktörlerin incelenmesi. Selçuk Üniversitesi Mühendislik, Bilim ve Teknoloji Dergisi, 4(3), 182-195.

Kasule, A. \& Ayan, K. (2019). Forecasting uganda's net electricity consumption using a hybrid pso-abc algorithm. Arabian Journal for Science and Engineering, 44(4), 3021-3031.

Kavaklioglu, K. (2011). Modeling and prediction of Turkey's electricity consumption using Support Vector Regression. Applied Energy, 88(1), 368-375.

Kavaklioglu, K. (2014). Robust electricity consumption modeling of Turkey using singular value decomposition. International Journal of Electrical Power \& Energy Systems, 54, 268-276.

Kavaklioglu, K., Ceylan, H., Ozturk, H. K. \& Canyurt, O. E. (2009). Modeling and prediction of Turkey's electricity consumption using artificial neural networks. Energy Conversion and Management, 50(11), 2719-2727.

Kayabasi, A. (2015). Kompakt mikroşerit antenlerin rezonans frekansının yapay sinir ăgları ve bulanık mantık sistemine dayalı uyarlanır ă̆ kullanarak hesaplanması (Doktora tezi). Mersin Üniversitesi, Fen Bilimleri Enstitüsü, Mersin.

Kaynar, O., Yüksek, A. G. \& Demirkoparan, F. (2016). Forecasting of Turkey's electricity consumption using support vector regression trained with genetic algorithm. Istanbul Üniversitesi Iktisat Fakültesi Mecmuasi, 66(2), 45-60.

Kaytez, F., Taplamacioglu, M. C., Cam, E. \& Hardalac, F. (2015). Forecasting electricity consumption: A comparison of regression analysis, neural networks and least squares support vector machines. International Journal of Electrical Power \& Energy Systems, 67, 431-438.

Kocadayı, Y., Erkaymaz, O. \& Uzun, R. (2017). Yapay sinir ağları ile Tr81 bölgesi yıllık elektrik enerjisi tüketiminin tahmini. International Symposium on Multidisciplinary Studies and Innovative Technologies, 239, Tokat.

Krishna, P. V., Babu, M. R. \& Ariwa, E. (Eds.). (2012). Global trends in information systems and software applications: 4th international conference, ObCom 2011, Vellore, TN, India, December 9-11, 2011, Part II. Proceedings (Vol. 270). Springer.

Kucukali, S. \& Baris, K. (2010). Turkey's short-term gross annual electricity demand forecast by fuzzy logic approach. Energy Policy, 38(5), 2438-2445.

Küçükdeniz, T. (2010). Long term electricity demand forcesting: An alternative approach with support vector machines. ÏÜ Mühendislik Bilimleri Dergisi, 1(1), 45-54.

Li, D. C., Chang, C. J., Chen, C. C. \& Chen, W. C. (2012). Forecasting short-term electricity consumption using the adaptive grey-based approach-An Asian case. Omega, 40(6), 767-773.

Li, K., Hu, C., Liu, G. \& Xue, W. (2015). Building's electricity consumption prediction using optimized artificial neural networks and principal component analysis. Energy and Buildings, 108, 106-113.

MacKay, D. J. C. (1992). Bayesian interpolation. Neural computation, 4(3), 415-447. 
Marino, D. L., Amarasinghe, K. \& Manic, M. (2016). Building energy load forecasting using deep neural networks. In 42nd Annual Conference of the IEEE Industrial Electronics Society, 7046-7051.

Oğcu, G., Demirel, O. F. \& Zaim, S. (2012). Forecasting electricity consumption with neural networks and support vector regression. Procedia-Social and Behavioral Sciences, 58, 1576-1585.

Okut, H. (2016). Bayesian regularized neural networks for small and big p data. In Artificial Neural NetworksModels and Applications. IntechOpen, https://www.intechopen.com/books/artificial-neural-networks-modelsand-applications/bayesian-regularized-neural-networks-for-small-n-big-p-data.

Özsoy, İ. \& Fırat, M. (2004). Kirişsiz döşemeli betonarme bir binada oluşan yatay deplasmanın yapay sinir ağları ile tahmini. DË̈ Mühendislik Fakültesi, Fen ve Mühendislik Dergisi, 6(1), 51-63.

Panklib, K., Prakasvudhisarn, C. \& Khummongkol, D. (2015). Electricity consumption forecasting in Thailand using an artificial neural network and multiple linear regression. Energy Sources, Part B: Economics, Planning, and Policy, 10(4), 427-434.

Pasini, A. (2015). Artificial neural networks for small dataset analysis. Journal of thoracic disease, 7(5), 953-960.

Pillai, N., Schwartz, S. L., Ho, T., Dokoumetzidis, A., Bies, R. \& Freedman, I. (2019). Estimating parameters of nonlinear dynamic systems in pharmacology using chaos synchronization and grid search. Journal of Pharmacokinetics and Pharmacodynamics, 46(2), 193-210.

Qiu, S., Jiang, M. Y., Pei, Z. L. \& Lu, Y. N. (2017). Text classification based on ReLU activation function of SAE algorithm. In International Symposium on Neural Networks, 44-50.

Tang, L., Wang, X., Wang, X., Shao, C., Liu, S. \& Tian, S. (2019). Long-term electricity consumption forecasting based on expert prediction and fuzzy Bayesian theory. Energy, 167, 1144-1154.

Torabi, M., Hashemi, S., Saybani, M. R., Shamshirband, S. \& Mosavi, A. (2019). A hybrid clustering and classification technique for forecasting short-term energy consumption. Environ. Prog. Sustainable Energy, 38, 66-76.

Tso, G. K. \& Yau, K. K. (2007). Predicting electricity energy consumption: A comparison of regression analysis, decision tree and neural networks. Energy, 32(9), 1761-1768.

Türkay, B. E. (2015). Türkiye'nin uzun dönem puant yük talebinin ve enerji ihtiyacının tahmin edilmesi. Elektrik Mühendisliği Dergisi, 453, 31-33.

Türkiye Elektrik Illetim A.Ş. (TEİAŞ). Erişim tarihi: 21.03.2018, https://www.teias.gov.tr/tr/sektor-raporlari

Türkiye İstatistik Kurumu (TUIK). Erişim tarihi: 22.03.2018, http://www.tuik.gov.tr/PreTablo.do?alt_id=1029

Veit, A., Goebel, C., Tidke, R., Doblander, C. \& Jacobsen, H. A. (2014). Household electricitydemand forecasting: benchmarking state-of-the-art methods. In Proceedings of the 5th International Conference On Future Energy Systems, ACM, 233-234.

Wong, T. T. (2015). Performance evaluation of classification algorithms by k-fold and leave-one-out cross validation. Pattern Recognition, 48(9), 2839-2846.

Xu, N., Dang, Y. \& Gong, Y. (2017). Novel grey prediction model with nonlinear optimized time response method for forecasting of electricity consumption in China. Energy, 118, 473-480.

Yadav, S. \& Shukla, S. (2016). Analysis of k-fold cross-validation over hold-out validation on colossal datasets for quality classification. In IEEE 6th International Conference on Advanced Computing (IACC), 78-83.

Yigit, V. (2011). Genetik algoritma ile Türkiye net elektrik enerjisi tüketiminin 2020 yılına kadar tahmini. Uluslararası Mühendislik Araştırma ve Geliştirme Dergisi, 3(2), 37-41. 
Yuan, C., Liu, S. \& Fang, Z. (2016). Comparison of China's primary energy consumption forecasting by using ARIMA (the autoregressive integrated moving average) model and GM (1, 1) model. Energy, 100, 384-390.

Zeng, Y. R., Zeng, Y., Choi, B. \& Wang, L. (2017). Multifactor-influenced energy consumption forecasting using enhanced back-propagation neural network. Energy, 127, 381-396.

Zhang, Y. \& Li, Q. (2019). A regressive convolution neural network and support vector regression model for electricity consumption forecasting. In Future of Information and Communication Conference, Springer, Cham., 33-45. 